\title{
Adsorption of Dye on Carbon Microparticles: Physicochemical Properties during Adsorption, Adsorption Isotherm and Education for Students with Special Needs \\ (Penjerapan Pewarna pada Mikrozarah Karbon: Sifat Fizikokimia semasa Penjerapan, Isoterma Penjerapan dan Pendidikan untuk Pelajar Berkeperluan Khas)
}

\author{
Rina Maryanti, Asep Bayu Dani Nandiyanto*, Tryastuti irawati Belliny Manullang, Achmad Hufad \\ $\&$ SUNARDI
}

\begin{abstract}
The purpose of this study was to demonstrate the adsorption of dye on carbon microparticles. We conducted two experiments: Understanding of the adsorption of dye on carbon microparticles. We used turmeric solution as a model of dye, in which this solution was contacted into commercially available carbon microparticles in the batch-typed adsorption reactor. The measurement results were then compared to several adsorption isotherm models, such as Langmuir, Freundlich, Temkin, and Dubinin-Radushkevich models; and finding teaching strategies to improve students ' understanding on the adsorption concept to students with special needs. As for the second part which is finding strategies to teach the obtained results and their concept of adsorption to students with special needs, we evaluated the strategies to eight students with intellectual disabilities in special schools in Kuningan District, Indonesia using a Single Subject Research method (equipped with pre-test, post-test, and experimental demonstration). The results showed that carbon can absorb dye and can be used as an alternative for wastewater treatment. The isotherm models have the linearity parameter $R^{2}$ of above $50 \%$, and the most suitable model is Freundlich. The models also confirmed favorable adsorption with multilayer structure and physical interaction between turmeric and carbon microparticles. Demonstrating experiments and informing the measurement results gave great impacts on students' comprehension, in which they have better understanding about the concept of adsorption compared to the conventional teaching method.
\end{abstract}

Keywords: Adsorption isotherm; adsorption of carbon; education; students with special needs; teaching

\section{ABSTRACT}

Tujuan kajian ini adalah untuk menunjukkan penjerapan pewarna pada mikrozarah karbon. Dua uji kaji telah dijalankan: Memahami penjerapan pewarna pada mikrozarah karbon. Larutan kunyit digunakan sebagai model pewarna dan larutan ini dihubungkan ke mikrozarah karbon yang tersedia secara komersial dalam reaktor penjerapan jenis batch. Hasil pengukuran kemudian dibandingkan dengan beberapa model isoterma penjerapan, seperti model Langmuir, Freundlich, Temkin dan Dubinin-Radushkevich; dan mencari strategi pengajaran untuk meningkatkan pemahaman pelajar mengenai konsep penjerapan kepada pelajar berkeperluan khas. Bagi bahagian kedua iaitu mencari strategi untuk mengajarkan hasil yang diperoleh dan konsep penjerapan mereka kepada pelajar berkeperluan khas, kami menilai strategi tersebut kepada lapan orang pelajar kurang upaya intelektual di sekolah khas di Kabupaten Kuningan, Indonesia menggunakan kaedah Penyelidikan Subjek Tunggal (dilengkapi dengan ujian pra, ujian pasca dan demonstrasi uji kaji). Hasil kajian menunjukkan bahawa karbon dapat menyerap pewarna dan dapat digunakan sebagai alternatif untuk rawatan air sisa. Model isoterma mempunyai parameter kelinearan $R^{2}$ lebih $50 \%$ dan model yang paling sesuai ialah Freundlich. Model itu juga mengesahkan penjerapan yang baik dengan struktur pelbagai lapisan dan interaksi fizikal antara mikrozarah kunyit dan karbon. Uji kaji menunjukkan dan pemberitahuan hasil pengukuran memberi impak yang besar terhadap pemahaman pelajar kerana mereka mempunyai pemahaman yang lebih baik mengenai konsep penjerapan berbanding kaedah pengajaran konvensional.

Kata kunci: Isoterma penjerapan; pelajar berkeperluan khusus; pendidikan; pengajaran; penjerapan karbon

\section{INTRODUCTION}

Adsorption is a process of forming a layer of gas on the surface of a solid or liquid (Paryanto et al. 2018). Two terms often used in the adsorption process are adsorbate and adsorbent. Adsorbate is a substance that is absorbed on the surface of other substances during the adsorption process (Nielsen \& Bandosz 2016) while adsorbents are substances where the surface can absorb other substances in the adsorption process (Stawiński et al. 2017). 
Many studies described the adsorption of materials, including the adsorption phenomenon (Hermann 2017), gas separation by adsorption processes (Lin et al. 2019), adsorption on solids (Zhang et al. 2019), the kinetics of adsorption on carbon from solution (Largitte \& Pasquere 2016), a useful adsorption isotherm (Baghdadi 2017), hydrogen adsorption in different carbon nanostructures (Pyle et al. 2016), and adsorption of organic molecules from aqueous solutions on carbon materials ( $\mathrm{Yu}$ et al. 2016).

One of the materials used as an adsorbent is carbon. Carbon is one of the abundant elements in the universe (Yan et al. 2019). Carbon particles are also widely studied because they have several advantages, such as harmless, inexpensive, high volumetric capacity, high reversible capacity, easily composited, rich, cheap, and stable.

There have been many reports on the synthesis and characterization of carbon materials, however, there is limited research on dye adsorption on carbon microparticles. Needless to say, the information is essential to understand the phenomenon occurred during the adsorption process which can be used for further uses, especially when using carbon as a catalyst and adsorbent. Furthermore, there are still no comprehensive approaches on teaching adsorption to students with special needs. Most of the researchers examined the adsorption learning process only on students in regular schools (Vandorn et al. 2011; Walkley 1973). Teachers consider that students with special needs do not have the ability to learn science because they have developmental and academic limitations (Maryanti et al. 2020a, 2020b). Every student has the capability that could be optimized. They understand the learning material if the education services accommodate their needs (Hidayat et al. 2020). Finding good strategies for teaching this concept is important and can be used as a model for further development of the way for improving students' comprehension.

Based on our previous studies regarding the adsorption process using silica (Ragadhita et al. 2019) and carbon (Nandiyanto et al. 2020a, 2017), the purpose of this study was to demonstrate adsorption of dye on carbon microparticles. The experiments in this study were conducted into two parts which are adsorption experiments and teaching process. The first part is the understanding of the adsorption of dye on carbon microparticles. In this part, the turmeric solution was used as a dye model in which this solution was contacted in commercially available carbon microparticles in the adsorption reactor of the batch type. The measurement results were then compared to several adsorption isotherm models, such as Langmuir, Freundlich, Temkin, and Dubinin-Radushkevich models. The second part included identifying strategies to teach students with special needs more about obtained findings and their understanding of adsorption. In this part, we evaluated the strategies to eight students with intellectual disabilities in special schools in Kuningan District, Indonesia using the Single Subject Research Method (consist of pre-test, post-test, and experimental demonstration). Experimental demonstration is one of the most effective ways of teaching students with special needs, particularly those with intellectual disabilities. They need attractive, concrete and interesting learning medias. In our previous studies, experimental demonstration were also used in science learning on the law of archimedes (Hidayat et al. 2020) and the heat transfer (Widodo et al. 2020).

Different from other studies that focused on the adsorption only, our study added the education part. Indeed, the main focus of this research was scientific research about adsorption of carbon microparticles, only one of its applications is education. The educational element only adds to originality to this research.

The results showed that carbon can absorb dye and can also be used as an alternative for wastewater treatment. The isotherm models have the linearity parameter $R^{2}$ of above $50 \%$ and the most suitable model is Freundlich. The models also confirmed favorable adsorption with multilayer structure and physical interaction between turmeric and carbon microparticles. Informing the measurement results gave great impacts on students' comprehension, in which they have better understanding about the concept of adsorption compared to the conventional teaching method.

\section{THEORITICAL KNOWLEDGE OF CARBON MICROPARTICLES ADSORPTION}

Isotherm Adsorption Model. To understand the concept of adsorption, four adsorption isotherm models were used in this study: Langmuir, Freundlich, Temkin, and Radushkevich Dubinin-models. The phenomenon during the adsorption process is predicted by the isotherm model, based on the concentration of the adsorbate and the amount of solution adsorbed per mass of adsorbent at equilibrium (Romero et al. 2005). Theoretically, the adsorbate attached to the surface of the adsorbent can be classified as monolayer and multilayer, as shown in Figure 1(a) and 1(b), respectively. Furthermore, the interaction between the surface of the adsorbent and adsorbing molecules under physisorption and chemisorption as described in the model is illustrated in Figure 1(a) for physical adsorption and Figure 1(b) for chemical adsorption. The concept of how the adsorbate adheres to the surface of the adsorbent is presented in Figure 2(a) and 2(b), respectively, which explains the concept of adsorption physically and chemically. 


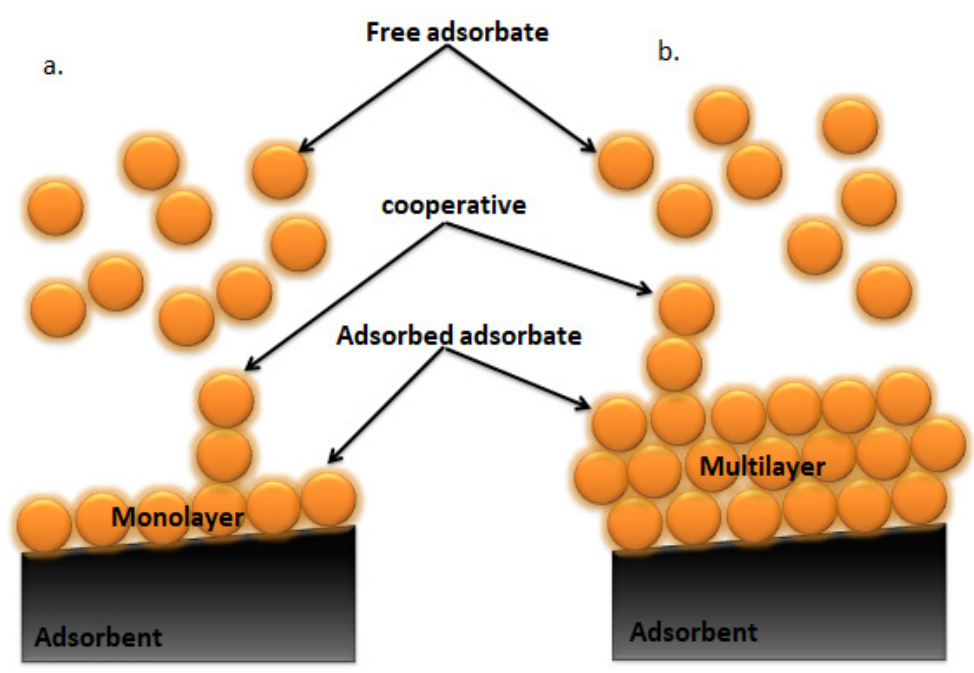

FIGURE 1. Illustration of adsorption process under monolayer (a) and multilayer (b)

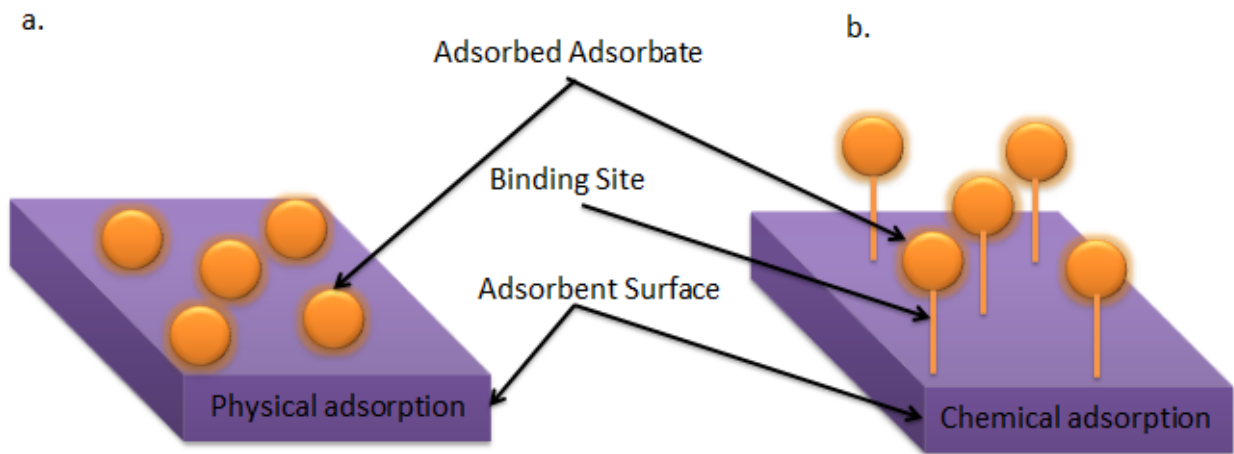

FIGURE 2. Illustration of interaction between adsorbate and adsorbent surface, (a) physical adsorption, and (b) the chemical adsorption

The isotherm model has the function of predicting phenomenon during the adsorption process, based on the adsorbate concentration and solution amount adsorbed per adsorbent mass at equilibrium. We used the derivation concept of correlations in Langmuir, Freundlich, Temkin, and Dubinin-Radushkevich models. Detailed information regarding the concept of isotherm adsorption is in our previous study (Nandiyanto 2020b). The Langmuir model has a function to the quantitative analysis for the formation of the monolayer adsorption model on the outer surface of the adsorbent. The Freundlich isotherm adsorption model has a feature for the analysis of a most widely used nonlinear adsorption model, which is adsorbed in multiple layers with a heterogeneous energy distribution on the adsorbent from the active site. The Temkin model has a feature to examine a correlation between indirect adsorbate interactions and the isotherm adsorption. All calculations are based on the initial concentration of adsorbate $\left(C_{o}\right.$; $\mathrm{mg} / \mathrm{L})$ and the concentration of adsorbate in equilibrium $\left(C_{e} ; \mathrm{mg} / \mathrm{L}\right)$. The Langmuir model is predicted using (1) and (2) (Chung et al. 2015).

$$
\begin{gathered}
\frac{1}{q_{e}}=\frac{1}{W_{\max } \cdot K_{L}} \frac{1}{C_{e}}+\frac{1}{q_{\max }} \\
R_{L}=\frac{1}{1+K_{L} C_{e}}
\end{gathered}
$$


where $K_{L}, q_{e}$, and $q_{\max }$ are the Langmuir's adsorption constants the monolayer adsorption capacity $(\mathrm{mg} / \mathrm{g})$, and the maximum adsorption capacity $\left(\mathrm{mg} \mathrm{g}^{-1}\right)$, respectively. The $R_{L}$ value is a separate factor that describes (Ayawei et al. 2017): $R_{L}>1$ is unfavorable adsorption, encouraging desorption; $\mathrm{R}_{\mathrm{L}}=1$ shows the linear adsorption process (independent adsorption in concentration); $\mathrm{R}_{\mathrm{L}}=0$ is an irreversible adsorption process where adsorbed cannot spread or desorb. This usually occurs in chemisorption; and $0<\mathrm{R}_{\mathrm{L}}<1$ is a favorable adsorption process, preventing the desorption process.

The Freundlich isotherm adsorption model analyzes using (3):

$$
\ln q_{e}=\ln K_{F}+\frac{1}{n} \ln C_{e}
$$

where $K_{f}$ is the Freundlich's constant (an estimated indicator of adsorption capacity). $n$ is a non-linear degree that describes (Ayawei et al. 2017): $n<1$ answers adsorption by chemical processes; $n=1$ implies linear adsorption (partitioning between two phases that are independent in concentration); and $n>1$ defines adsorption by physical processes.

The definition of $n$ can be derived again using $1 / n$ (a function of the strength of adsorption in the adsorption process), which is described as (Ayawei et al. 2017): $1 / n<1$ answer normal adsorption; and $1 / n>1$ implies cooperative adsorption where adsorbed adsorbs affect and affect adsorption free adsorption.

The Temkin model illustrates factors with correlation (4):

$$
q_{e}=B_{T}\left(\ln C_{e}\right)+\left(B_{T} \ln A_{T}\right)
$$

where $A_{T}$ is the equilibrium binding constant; and $\beta_{T}$ is the Temkin isotherm constant, informing (Ayawei et al. 2017): $\beta_{\mathrm{T}}<8 \mathrm{~kJ}$ implies physisorption; and $\beta_{\mathrm{T}}>8 \mathrm{~kJ}$ answers chemisorption.

Dubinin-Radushkevich isotherm uses the concept of correlation (5), (6) and (7):

$$
\begin{aligned}
& \ln q_{e}=\ln q_{s}-\beta \varepsilon^{2} \\
& \varepsilon=R T \ln \left[1+\frac{1}{C_{e}}\right]
\end{aligned}
$$

$$
E=\frac{1}{\sqrt{2 \beta}}
$$

where $q_{s}, \beta$, and $\varepsilon$ represent the theoretical isotherm of saturation capacity, the Dubinin-Radushkevich theory of isotherm saturation capacity, and Polanyi potential, respectively. $T$ is the absolute temperature $(K)$; and $R$ is the Boltzmann gas constant $\left(8,314 \mathrm{Jmol}^{-1} \mathrm{~K}^{-1}\right) . E$ is energy, describing (Ayawei et al. 2017): $E<8 \mathrm{kJmol}^{-1}$ is chemisorption; $E>8 \mathrm{kJmol}^{-1}$ is physisorption.

The adsorption efficiency is measured as (8):

$$
\% E=\left(\frac{C_{o}-C_{e}}{C_{o}}\right) \times 100 \%
$$

where $\% E$ is the adsorption efficiency $(\%)$.

\section{MATERIALS AND METHODS}

\section{MATERIALS}

Materials used are carbon (Daiyu Water Filter, Japan) and turmeric powder (Desaku turmeric powder, PT. Motasa, Indonesia).

\section{ADSORPTION PROCESS}

Adsorption tests were done by adding carbon particles (0.5 g; with a specific size of 500, 1000, 1500, and 2000 $\mu \mathrm{m})$ into $15 \mathrm{~mL}$ of turmeric solution with a specific concentration (i.e. 100, 80, 60, 40, 20, and 0 ppm). Every $5 \mathrm{~min}$, turmeric solution and turmeric solution plus carbon were measured for concentration using the concept of light penetration (Figure 3). It is intended to make the adsorption task simpler for the students to understand. In short, the testing apparatus in Figure 3 consists of a LED flashlight, a solution (containing turmeric and carbon microparticles) and lux meter. Theoretically, the light from the battery is transmitted to the lux meter (HP OPPO A3; Indonesia). The maximum adsorption yield and absorption peak were measured and compared with standard isotherm adsorption models: Freundlich, Langmuir, Temkin, and Dubin-Radushkevich models.

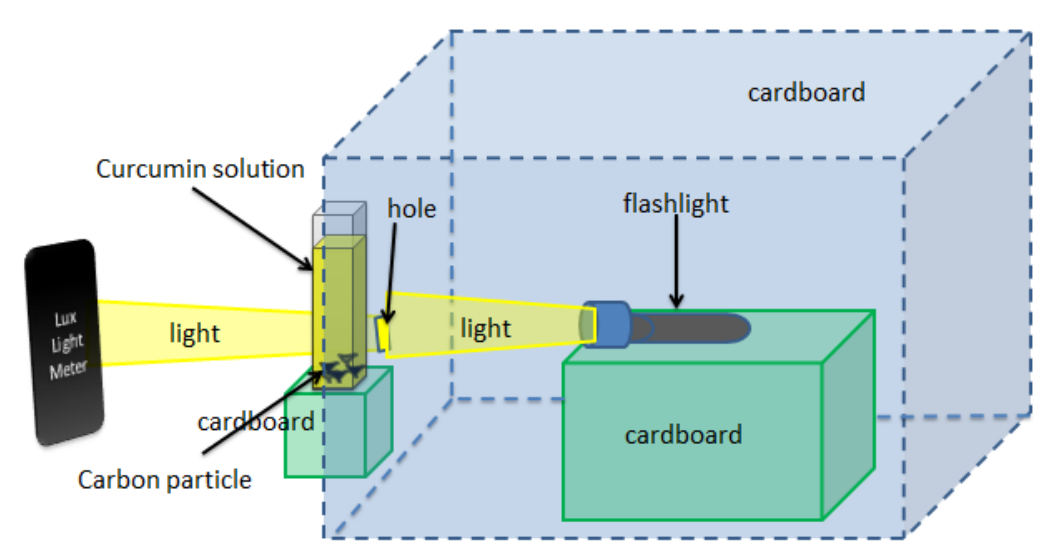

FIGURE 3. Carbon adsorption test by calculating the concentration of the solution 


\section{TEACHING STRATEGY}

This study used a single-subject research method. The subjects in this study were 8 students with intellectual disabilities in special schools in Kuningan district, Indonesia. We obtained data through a number of questions provided (pretest-posttest). Parents and teachers played important role in helping the process of obtaining data in the field. We conducted interviews with teacher to obtain information about students' abilities such as students' level of intelligence, concentration, communication and motor skills. All information on student ability levels was assessed using a score of 5 , on a scale of 0 (know nothing), 1 (poor), 2 (fair) 3 (quite good), 4 (good), 5 (excellent).

The teaching process used two learning methods:

\section{The conventional method (the first session)}

The conventional method is one of the teacher-centered methods. The learning process includes talks, assignments, and questions and answers (Gopalan \& Klann 2017; Hidayat et al. 2020). The teacher usually talks about method to explain the adsorption material to students and also provides a pretest and posttest to determine the level of student understanding. We used a short question type test with yes or no answer choices. We provided 21 questions related to the adsorption concept (Table 4). Each question has a score of 1 . The maximum score the student gets is $21 \times 100: 21=100$ (the score obtained is multiplied by 100 divided by twenty one).

\section{The experimental demonstration method (the second session)}

In the second session, the experimental demonstration method was conducted by observing the adsorption of turmeric. Initially, the teacher explained the adsorption material, equipment, and materials used to conduct the experiment. We used several tools and materials to teach material about adsorption. We also used natural turmeric powder, carbon, mineral water, measuring cups, scales, clear glasses, battery, and cellphone application for lux meters. During this session, the teacher demonstrated how to weigh the carbon microparticles, formulated a turmeric solution with concentrations of $100,80,60$, 40,20 , and 0 ppm and put carbon microparticles into a turmeric solution. The solution was kept for several min and measured using the light penetration concept. Pretest and posttest were given to students in each learning session. We used a short question type test, same with the conventional method. We provided 21 questions related to the adsorption concept (Table 4). Each question has a score of 1 . The maximum score the student gets is $21 \times 100: 21=100$ (the score obtained is multiplied by 100 divided by twenty one). In contrast to conventional methods, we used concrete and interesting learning media in experimental demonstrations. The teaching process for students with special needs required special techniques. In particular, teachers needed to provide attractive methods to attract student concentration and focus.

\section{RESULTS AND DISCUSSION}

\section{ADSORPTION OF DYE ON THE CARBON MICROPARTICLES}

Figure 4(a) shows an image of carbon microparticles. The analysis results showed that the particle sizes are in the range between 500 and $2000 \mathrm{um}$. The results of the particle size distribution using a sieve test are shown in Figure 4(b), identifying most particle sizes in the range of 500 and $1000 \mathrm{um}$.

Figure 5 shows the FTIR analysis results of samples, including as-purchased carbon particles, turmeric powder and carbon/turmeric (i.e. as-processed carbon particles with turmeric solution). The FTIR results showed that turmeric has strong signal at about $2300 \mathrm{~cm}^{-1}$. This signal appeared in the sample of carbon/turmeric, informing there is the interaction of turmeric on the surface of carbon.
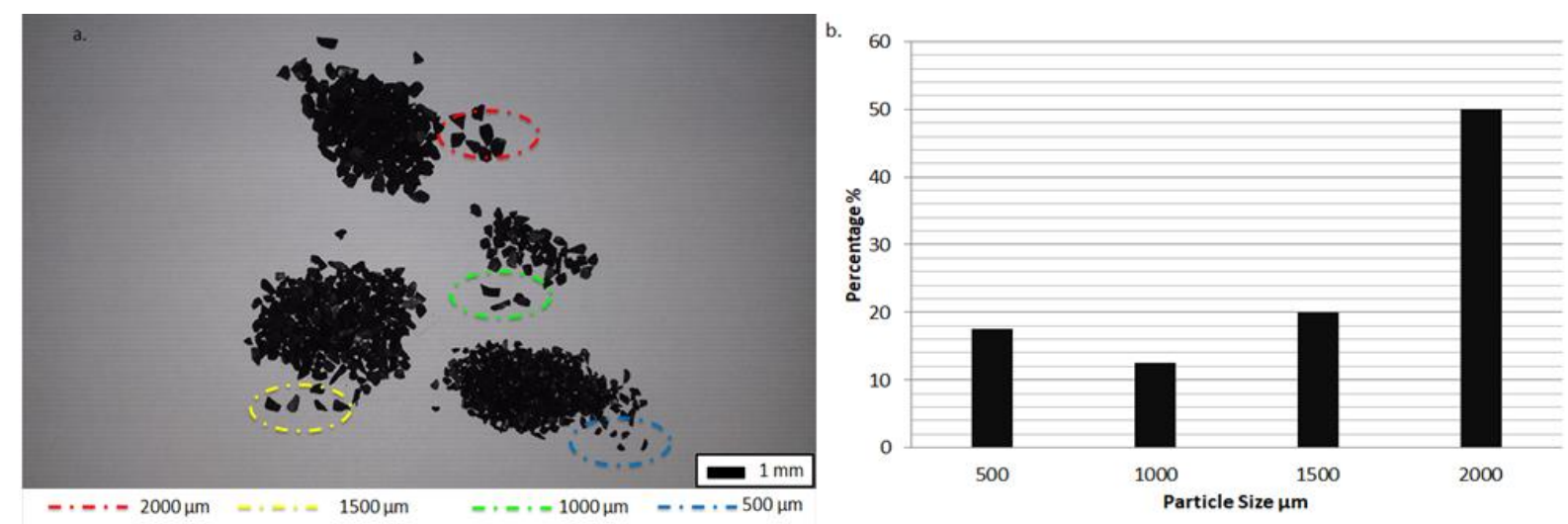

FIGURE 4. Microscope image (a) of carbon particles with their particle size distribution (b) 


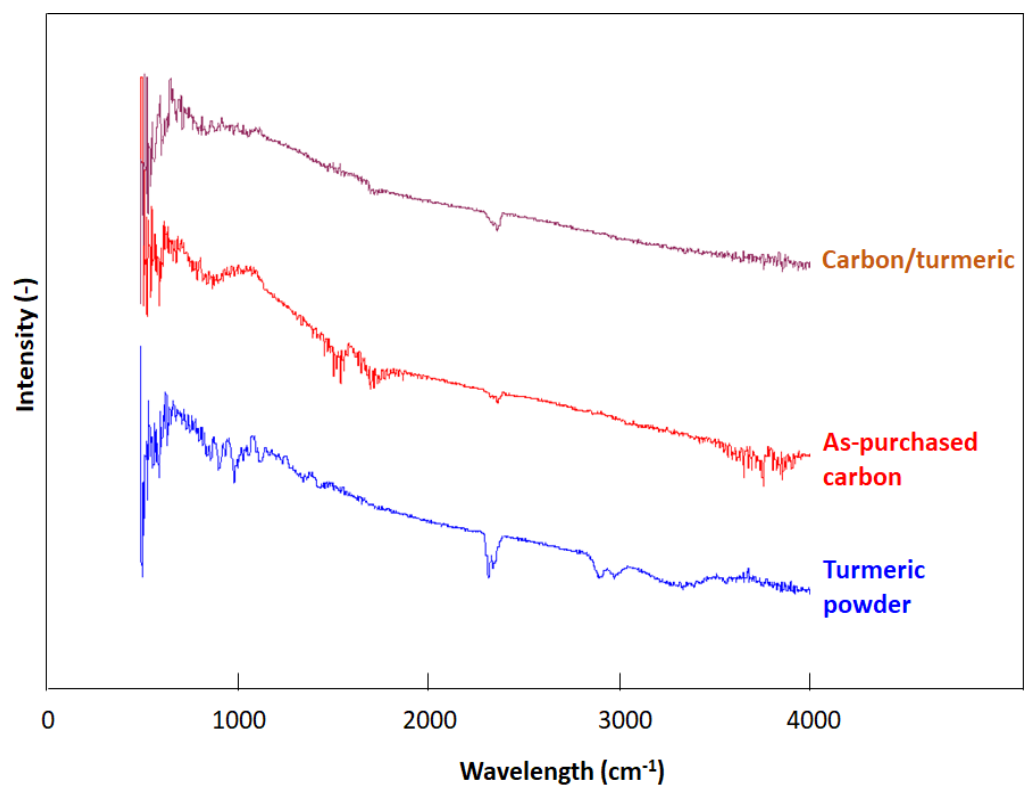

FIGURE 5. The FTIR analysis results of carbon particles with various sizes

\section{ADSORPTION CHARACTERISTICS OF CARBON} MICROPARTICLES BASED ON ISOTHERM MODELS

Analysis of adsorption was made by calculating linearization from adsorption data. Linear analysis based on (1)-(7) is presented in Figures 6, 7, 8, and 9, respectively, according to the Langmuir, Freundlich, Temkin, and Dubinin-Radushkevich models.
Detailed information for the adsorption parameters gained from Figures 6, 7, 8, and 9 is presented in Table 1. This table also discusses the results of the parameters to confirm what phenomenon occurred during the adsorption process.

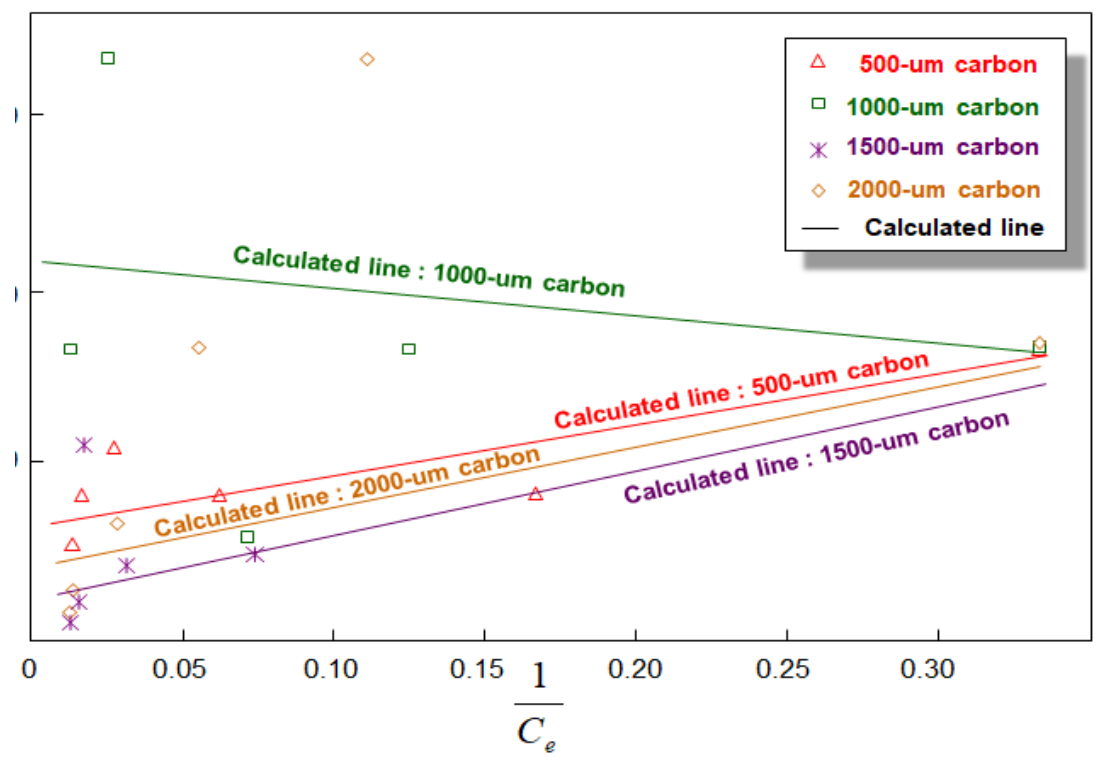

FIGURE 6. Langmuir adsorption isotherm model 


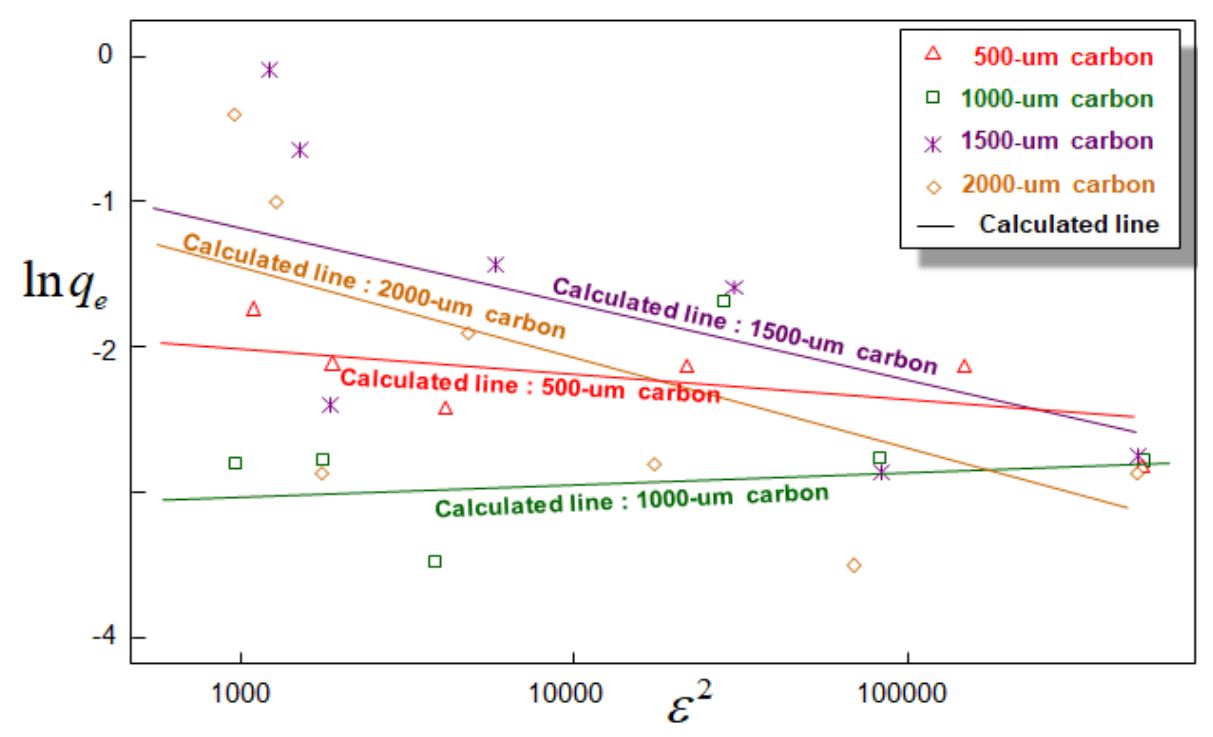

FIGURE 7. Freundlich adsorption isotherm model

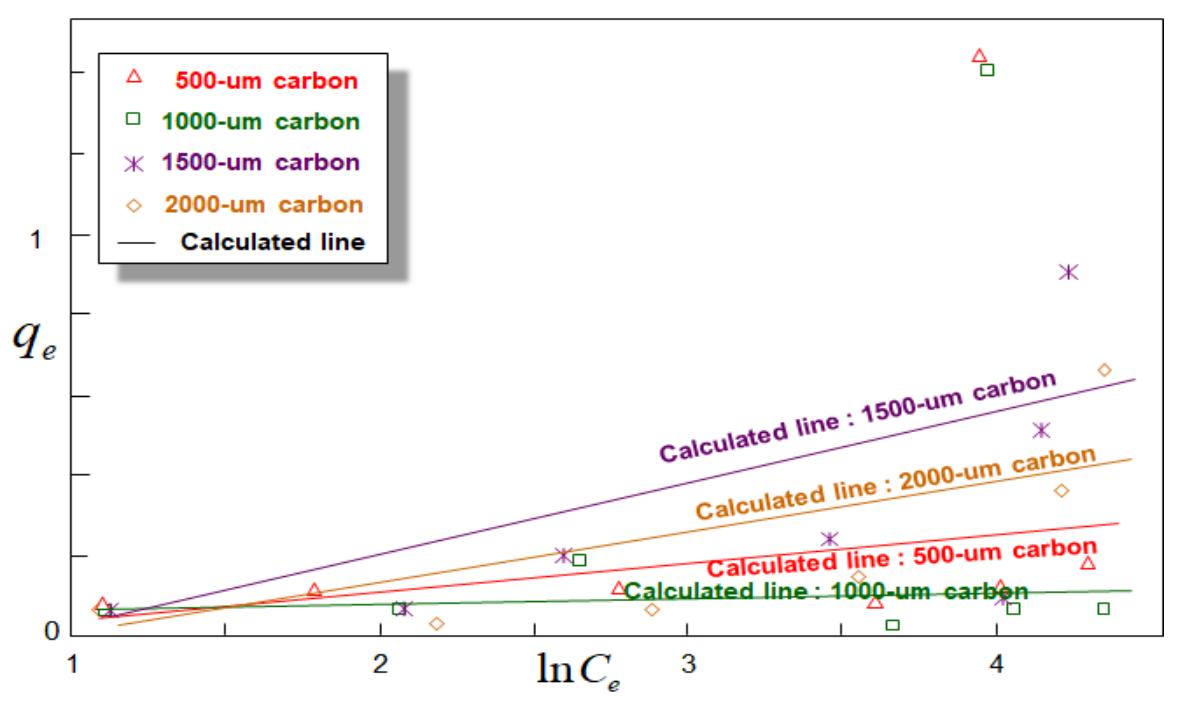

FIGURE 8. Temkin adsorption isotherm model

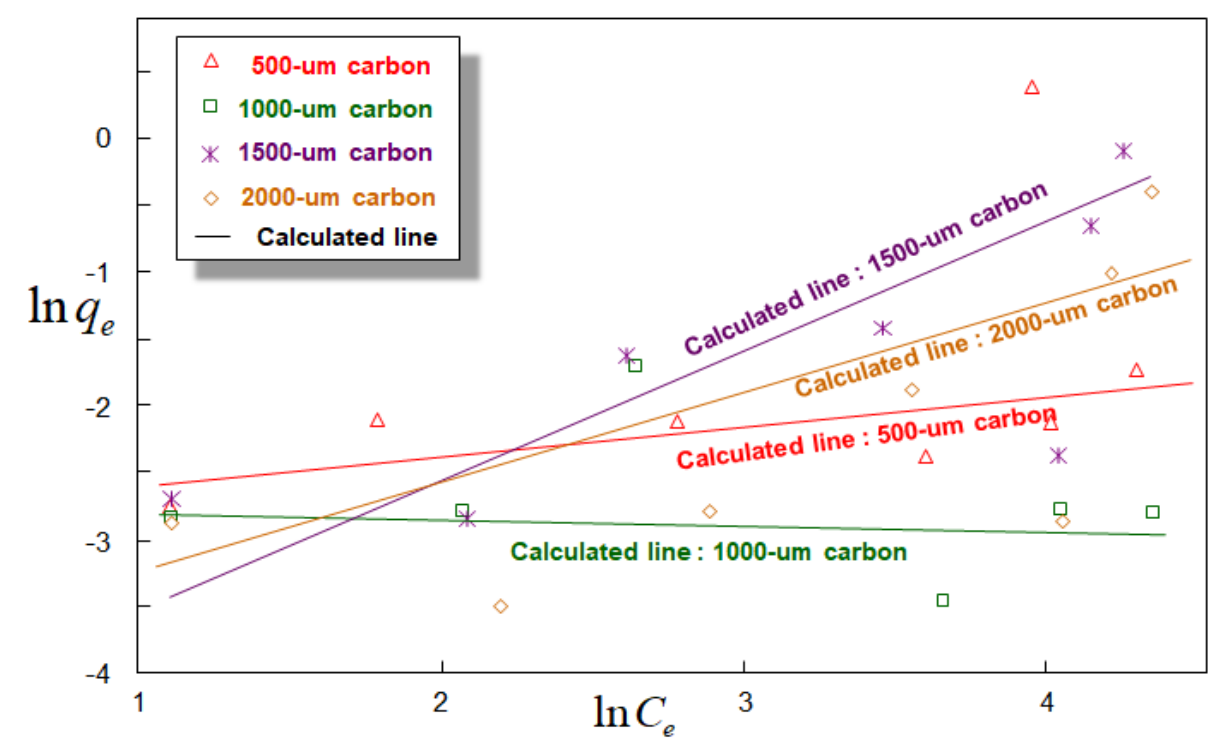

FIGURE 9. Dubinin-Radushkevich adsorption isotherm model 
Based on the $R^{2}$ calculation in Table 1 , the adsorption is suitable with the models, sequentially Freundlich $>$ Temkin $>$ Langmuir $>$ Dubinin-Radushkevich. The Freundlich model predicted the adsorption of turmeric that occurs on the surface of carbon microparticles, as follows: Happening on the heterogeneous surface of the adsorbent; having interactions between carbon and turmeric in the multilayer adsorption; and having physical adsorption phenomena.

The illustration of the multilayer adsorption process with the physical interactions is presented in Figure 10.

TABLE 1. Detailed parameters of Langmuir, Freundlich, Temkin, and the Radushkevich-Dubinin models

\begin{tabular}{|c|c|c|c|c|c|c|}
\hline \multirow{2}{*}{ Model } & \multirow{2}{*}{ Parameter } & \multicolumn{4}{|c|}{ Particle size $(\mu \mathrm{m})$} & \multirow{2}{*}{ Notes } \\
\hline & & 2000 & 1500 & 1000 & 500 & \\
\hline \multirow{5}{*}{ Langmuir } & $q_{\max }\left(\mathrm{mg} \mathrm{g}^{-1}\right)$ & 0.10 & 0.23 & 0.07 & 0.18 & $\begin{array}{l}\text { The maximum monolayer } \\
\text { adsorption capacity }\end{array}$ \\
\hline & $K_{L}\left(\mathrm{~L} \mathrm{mg}^{-1}\right)$ & 0.2821 & 0.1033 & 5.2541 & 0.1865 & Langmuir adsorption constant \\
\hline & $R_{L}$ & 0.1759 & 0.3372 & 0.0158 & 0.2485 & $\begin{array}{c}0<R_{L}<1 \text {, indicating favorable } \\
\text { adsorption }\end{array}$ \\
\hline & $R^{2}$ & 0.1523 & 0.5473 & 0.0010 & 0.5520 & The correlation coefficient \\
\hline & $\mathrm{D} G f\left(\mathrm{~kJ} \mathrm{~mol}^{-1}\right)$ & -34.89 & -37.38 & -27.64 & -35.91 & $\begin{array}{l}\mathrm{D} G f<0, \text { informing } \\
\text { spontaneous process }\end{array}$ \\
\hline \multirow{5}{*}{ Freundlich } & $n$ & 1.5548 & 0.6495 & 5.0043 & 2.3466 & $\begin{array}{c}n>1 \text {, defining adsorption with } \\
\text { physical process }\end{array}$ \\
\hline & $1 / n$ & 0.6432 & 0.6495 & 0.1998 & 0.4261 & $\begin{array}{l}1 / n=0-1, \text { indicating } \\
\text { favorable adsorption }\end{array}$ \\
\hline & $K_{f}\left(\mathrm{mg} \mathrm{g}^{-1}\right)$ & 0.0144 & 0.0245 & 0.0535 & 0.0424 & The Freundlich constant \\
\hline & $R^{2}$ & 0.4833 & 0.5530 & 0.0358 & 0.2593 & The correlation coefficient \\
\hline & $\mathrm{D} G f\left(\mathrm{~kJ} \mathrm{~mol}^{-1}\right)$ & -42.25 & -40.94 & -39.01 & -39.58 & $\begin{array}{l}\mathrm{D} G f<0, \text { informing } \\
\text { spontaneous process }\end{array}$ \\
\hline \multirow{6}{*}{ Temkin } & $A_{T}\left(L g^{-1}\right)$ & 0.2070 & 0.2593 & 0.3958 & 0.3715 & $\begin{array}{c}\text { The equilibrium binding } \\
\text { constant }\end{array}$ \\
\hline & $B_{T}\left(\mathrm{~J} \mathrm{~mol}^{-1}\right)$ & 0.1216 & 0.1680 & 0.1209 & 0.1457 & $\begin{array}{l}\text { For size }>500 \mathrm{um}, B_{T}<8 \mathrm{~kJ}, \\
\text { indicating physical adsorption }\end{array}$ \\
\hline & $R_{l}$ & 0.3954 & 0.4261 & 0.0838 & 0.1278 & The correlation coefficient \\
\hline & $K_{T}$ & 0.0023 & 0.0005 & 0.0031 & 0.0025 & \\
\hline & $\mathrm{DH}\left(\mathrm{kJ} \mathrm{mol}^{-1}\right)$ & 44.5004 & 45.4846 & 31.6546 & 29.8980 & \\
\hline & $R^{2}$ & 0.3167 & 0.3385 & 0.2558 & 0.3212 & \\
\hline \multirow{4}{*}{$\begin{array}{l}\text { Dubinin- } \\
\text { Radushkevich }\end{array}$} & $q_{s}\left(\mathrm{mg} \mathrm{g}^{-1}\right)$ & 0.13 & 0.24 & 0.11 & 0.20 & $\begin{array}{l}\text { The maximum adsorption } \\
\text { capacity of adsorbent }\end{array}$ \\
\hline & $\beta\left(\mathrm{mol}^{2} \mathrm{~kJ}^{-2}\right)$ & 1.98 & 3.15 & 1.36 & 2.51 & $\begin{array}{l}\text { The Dubinin-Radushkevich } \\
\text { isotherm saturation capacity }\end{array}$ \\
\hline & $E\left(\mathrm{~kJ} \mathrm{~mol}^{-1}\right)$ & 0.5024 & 0.3986 & 0.6058 & 0.4460 & $\begin{array}{c}E<8 \mathrm{~kJ} / \mathrm{mol} \text {, replying } \\
\text { physical adsorption }\end{array}$ \\
\hline & $R^{2}$ & 0.1105 & 0.3105 & 0.0395 & 0.2106 & The correlation coefficient \\
\hline
\end{tabular}




\section{TEACHING PROCESS TO STUDENTS WITH SPECIAL} NEEDS

One of the applications in the present adsorption process is educating students regarding the important of adsorption process. Table 2 shows the level of student ability in aspects of development, namely the level of intelligence, concentration, communication, and motor skills. All students have the same level of ability, indicating that they can embrace the teaching and learning process despite additional specific treatment. Tables 3 and 4 shows the students' pretest and post-test scores. Before conducting learning using the experimental demonstration method, all students had a score below 70 for the pretest. After the teacher gave learning material using the experimental demonstration method, more than $50 \%$ of students had grades above 70 . The experimental demonstration shows its effectiveness for improving students' understanding although students with special needs have difficulties in understanding abstract concept (Maryanti et al. 2020a, 2020b).

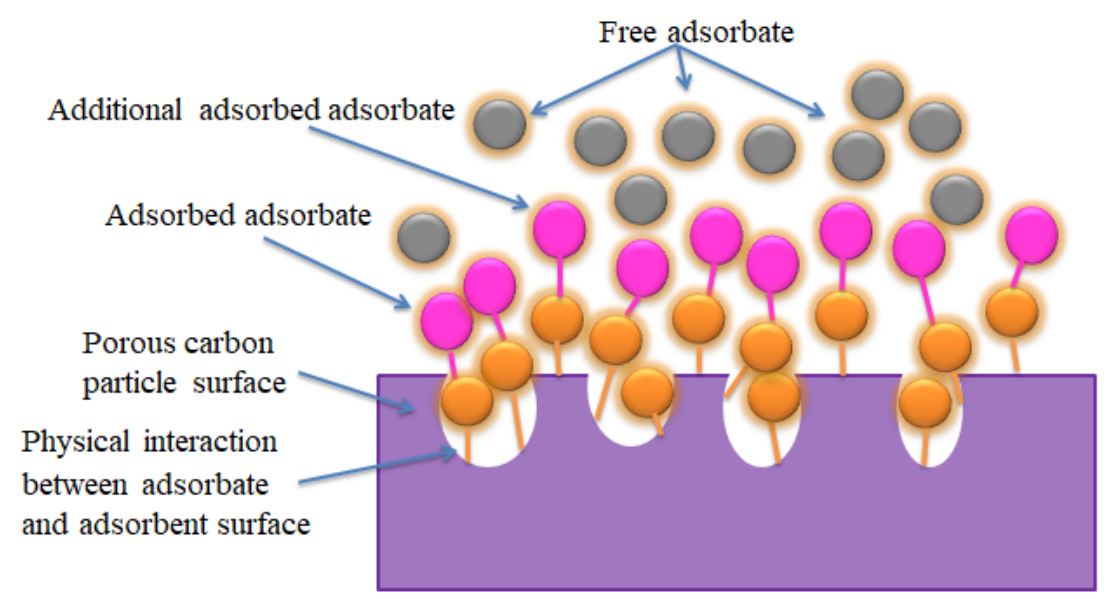

FIGURE 10. Illustration of adsorption process using carbon (as the adsorbent) and turmeric (as the adsorbate)

TABLE 2. Level of students ability

\begin{tabular}{cccccccccc}
\hline No & $\begin{array}{c}\text { Aspect of students } \\
\text { ability }\end{array}$ & Student A & Student B & Student C & Student D & Student E & Student F & Student G & Student H \\
\hline 1 & Intelligence & 3 & 3 & 2 & 2 & 2 & 2 & 2 & 2 \\
2 & concentration & 3 & 2 & 3 & 3 & 2 & 2 & 2 & 2 \\
3 & communication & 2 & 2 & 2 & 2 & 2 & 2 & 2 & 2 \\
4 & motor skills & 3 & 3 & 3 & 3 & 3 & 3 & 2 & 3 \\
\hline
\end{tabular}

TABLE 3. The level of student knowledge about carbon adsorption from the pretest and posttest results

\begin{tabular}{ccccc}
\hline No & Subject & Pretest & $\begin{array}{c}\text { Posttest after } \\
\text { conventional teaching }\end{array}$ & $\begin{array}{c}\text { Posttest after experimental } \\
\text { demonstration }\end{array}$ \\
\hline 1 & Student A & 23.81 & 28.57 & 85.71 \\
2 & Student B & 19.05 & 23.81 & 76.19 \\
3 & Student C & 19.05 & 28.57 & 71.43 \\
4 & Student D & 19.05 & 23.81 & 76.19 \\
5 & Student E & 19.05 & 23.81 & 76.19 \\
6 & Student F & 19.05 & 23.81 & 66.67 \\
7 & Student G & 19.05 & 23.81 & 66.67 \\
8 & Student H & 19.05 & 23.81 & 66.67 \\
\hline
\end{tabular}


TABLE 4. Analysis of the percentage of students' answer to the carbon adsorption concept material being taught

\begin{tabular}{|c|c|c|c|c|}
\hline No & Concept & Pretest & $\begin{array}{c}\text { Posttest after } \\
\text { conventional teaching }\end{array}$ & $\begin{array}{l}\text { Posttest after } \\
\text { experimental } \\
\text { demonstration }\end{array}$ \\
\hline 1 & Definition of solution & 100 & 100 & 100 \\
\hline 2 & Definition of solvents & 100 & 100 & 100 \\
\hline 3 & Definition of solutes & 0 & 0 & 100 \\
\hline 4 & $\begin{array}{l}\text { Understanding of mineral water is a } \\
\text { solvent }\end{array}$ & 12 & 100 & 100 \\
\hline 5 & Understanding of types of solutes & 0 & 25 & 100 \\
\hline 6 & Definition of solution concentration & 0 & 0 & 12 \\
\hline 7 & $\begin{array}{l}\text { Definition of a high concentration } \\
\text { solution }\end{array}$ & 0 & 0 & 100 \\
\hline 8 & $\begin{array}{l}\text { Definition of a low concentration } \\
\text { solution }\end{array}$ & 0 & 0 & 100 \\
\hline 9 & $\begin{array}{l}\text { Effect of low concentrated solution } \\
\text { on light }\end{array}$ & 0 & 0 & 100 \\
\hline 10 & $\begin{array}{l}\text { Effect of high concentrated solution } \\
\text { on light }\end{array}$ & 0 & 0 & 100 \\
\hline 11 & $\begin{array}{l}\text { Comparison of light in high } \\
\text { concentrated solutions }\end{array}$ & 0 & 0 & 37 \\
\hline 12 & $\begin{array}{l}\text { Comparison of low in high } \\
\text { concentrated solutions }\end{array}$ & 0 & 0 & 100 \\
\hline 13 & Understanding of turmeric color & 100 & 100 & 100 \\
\hline 14 & $\begin{array}{l}\text { The effect of turmeric on } \\
\text { concentration }\end{array}$ & 0 & 0 & 100 \\
\hline 15 & Understanding of carbon color & 100 & 100 & 100 \\
\hline 16 & $\begin{array}{l}\text { The effect of carbon particle on } \\
\text { concentration }\end{array}$ & 0 & 0 & 100 \\
\hline 17 & Definition of adsorption & 0 & 0 & 62 \\
\hline 18 & Definition of adsorbate & 0 & 0 & 0 \\
\hline 19 & Definition of adsorbent & 0 & 0 & 0 \\
\hline 20 & Type of adsorbate & 0 & 0 & 12 \\
\hline 21 & Type of adsorbent & 0 & 0 & 12 \\
\hline
\end{tabular}

\section{CONCLUSION}

This study aimed to demonstrate the adsorption of dye on carbon microparticles. The experiment was carried out in two parts. The first part is an understanding of the adsorption of dyes on carbon microparticles using turmeric. The measurement results are then compared with several adsorption isotherm models, such as
Langmuir, Freundlich, Temkin, and Dubinin-Radushkevich models. The second part is to find strategies to teach the results obtained and the concept of adsorption to students with special needs. We evaluated the strategy to eight students with intellectual disabilities in special schools. The results showed that carbon can absorb dyes and can be used as an alternative to wastewater treatment. The isotherm 
model has a linearity parameter of $R^{2}$ above $50 \%$ and the most suitable model is Freundlich with a multilayer structure and the physical interactions between turmeric and carbon microparticles. The learning outcomes using the experimental demonstration method have a major impact on students' understanding, compared to conventional teaching methods.

\section{ACKNOWLEDGEMENTS}

RM acknowledged Sekolah Pasca Sarjana for giving the $\mathrm{PhD}$ scholarship. We also thank teachers and parents of four special needs school (Sekolah Luar Biasa) in Kuningan, Indonesia for assisting this experiment. This study was supported by Bangdos Universitas Pendidikan Indonesia and RISTEK BRIN for Grant in Aid Penelitian Unggulan Perguruan Tinggi.

\section{REFERENCES}

Ayawei, N., Ebelegi, A.N. \& Wankasi, D. 2017. Modelling and interpretation of adsorption isotherms. Journal of Chemistry 2017: 1-11.

Baghdadi, M. 2017. UT (University of Tehran) isotherm as a novel and useful adsorption isotherm for investigation of adsorptive removal of pollutants. Journal of Environmental Chemical Engineering 5(2): 1906-1919.

Chung, H.K., Kim, W.H., Park, J., Cho, J., Jeong, T.Y. \& Park, P.K., 2015. Application of Langmuir and Freundlich isotherms to predict adsorbate removal efficiency or required amount of adsorbent. Journal of Industrial and Engineering Chemistry 28: 241-246.

Gopalan, C. \& Klann, M.C. 2017. The effect of flipped teaching combined with modified team-based learning on student performance in physiology. Advances in Physiology Education 41(3): 363-367.

Hermann, J., DiStasio Jr., R.A. \& Tkatchenko, A. 2017. Firstprinciples models for van der Waals interactions in molecules and materials: Concepts, theory, and applications. Chemical Reviews 117(6): 4714-4758.

Hidayat, D.S., Rakhmat, C., Fattah, N., Rochyadi, E., Nandiyanto, A.B.D. \& Maryanti, R. 2020. Understanding archimedes law: What the best teaching strategies for vocational high school students with hearing impairment. Journal of Technical Education and Training 12(1): 229-237.

Largitte, L. \& Pasquier, R. 2016. A review of the kinetics adsorption models and their application to the adsorption of lead by an activated carbon. Chemical Engineering Research and Design 109(2016): 495-504.

Lin, R.B., Xiang, S., Xing, H., Zhou, W. \& Chen, B. 2019. Exploration of porous metal-organic frameworks for gas separation and purification. Coordination Chemistry Reviews 378(2019): 87-103.

Maryanti, R., Hufad, A., Sunardi \& Nandiyanto, A.B.D. 2020a. Understanding Covid-19 particle contagion through aerosol droplets for students with special needs. Journal of Engineering Science and Technology 15(3): 1909-1920.

Maryanti, R., Hufad, A., Sunardi, Nandiyanto, A.B.D. \& Manullang, T.I.B. 2020b. Understanding Coronavirus
(COVID-19) as a small particle to students with special needs. Horizon 2(1): 121-130.

Nandiyanto, A.B.D. 2020a. Isotherm adsorption of carbon microparticles prepared from pumpkin (Cucurbita maxima) seeds using two-parameter monolayer adsorption models and equations. Moroccan Journal of Chemistry 8(3): 745-761.

Nandiyanto, A.B.D., Girsang, G.C.S., Maryanti, R., Ragadhita, R., Anggraeni, S., Fauzi, F.M., Sakinah, P., Astuti, A.P., Usdiyana, D., Fiandini, M. \& Dewi, M.W. 2020. Isotherm adsorption characteristics of carbon microparticles prepared from pineapple peel waste. Communications in Science and Technology 5(1): 31-39.

Nandiyanto, A.B.D., Putra, Z.A., Andika, R., Bilad, M.R., Kurniawan, T., Zulhijah, R. \& Hamidah, I. 2017. Porous activated carbon particles from rice straw waste and their adsorption properties. Journal of Engineering Science and Technology 12(Special Issue): 1-11.

Nielsen, L. \& Bandosz, T.J. 2016. Analysis of the competitive adsorption of pharmaceuticals on waste derived materials. Chemical Engineering Journal 287(2016): 139-147.

Paryanto, P., Arsyad, M.F. \& Aji, M.F.I. 2018. Penentuan nilai kesetimbangan adsorbsi zat warna alami kulit mahoni ke dalam kain dengan proses batch. Jurnal Inovasi Teknik Kimia 3(2): 1-7.

Pyle, D.S., Gray, E.M. \& Webb, C.J. 2016. Hydrogen storage in carbon nanostructures via spillover. International Journal of Hydrogen Energy 41(42): 19098-19113.

Ragadhita, R., Nandiyanto, A.B.D., Nugraha, W.C. \& Mudzakir, A. 2019. Adsorption isotherm of mesopore-free submicron silica particles from rice husk. Journal of Engineering Science and Technology 14(4): 2052-2062.

Romero, G.J., Peralta-Videa, J.R., Rodriguez, E., Ramirez, S.L. \& Gardea-Torresdey, J.L. 2005. Determination of thermodynamic parameters of $\mathrm{Cr}$ (VI) adsorption from aqueous solution onto Agave lechuguilla biomass. The Journal of Chemical Thermodynamics 37(4): 343-347.

Stawiński, W., Węgrzyn, A., Dańko, T., Freitas, O., Figueiredo, S. \& Chmielarz, L. 2017. Acid-base treated vermiculite as high performance adsorbent: Insights into the mechanism of cationic dyes adsorption, regeneration, recyclability and stability studies. Chemosphere 173: 107-115.

VanDorn, D., Ravalli, M.T., Small, M.M., Hillery, B. \& Andreescu, S. 2011. Adsorption of arsenic by iron oxide nanoparticles: A versatile, inquiry-based laboratory for a high school or college science course. Journal of Chemical Education 88(8): 1119-1122.

Walkley, G.H. 1973. A sixth-form teaching unit on the langmuir adsorption isotherm. School Science Review 54(189): 709717.

Widodo, A.P.A., Hufad, A., Sunardi \& Nandiyanto, A.B.D. 2020. Collaborative teaching in heat transfer for slow learner students. Journal of Engineering Science and Technology 15(1): 11-21.

Yan, F., Sun, Z., Zhang, H., Sun, X., Jiang, Y. \& Bai, Z. 2019. The fluorescence mechanism of carbon dots, and methods for tuning their emission color: A review. Microchimica Acta 186(8): 583-593.

Yu, F., Li, Y., Han, S. \& Ma, J. 2016. Adsorptive removal of antibiotics from aqueous solution using carbon materials. 
Chemosphere 153(2016): 365-385.

Zhang, N., Xiao, J., Bénard, P. \& Chahine, R. 2019. Single-and double-bed pressure swing adsorption processes for $\mathrm{H}_{2} / \mathrm{CO}$ syngas separation. International Journal of Hydrogen Energy 44(48): 26405-26418.

Rina Maryanti, Tryastuti Irawati Belliny Manullang, Achmad Hufad \& Sunardi

Departemen Pendidikan Khusus

Universitas Pendidikan Indonesia

Bandung

Indonesia
Asep Bayu Dani Nandiyanto*

Departemen Kimia

Universitas Pendidikan Indonesia

Bandung

Indonesia

*Corresponding author; email: nandiyanto@upi.edu

Received: 8 August 2020

Accepted: 21 August 2020 